\title{
POLITIK HUKUM PERUNDANG-UNDANGAN : MEMPERTEGAS REFORMASI LEGISLASI YANG PROGRESIF
}

\author{
(Political Law of Legislation : Reinforce the Progressive Legislation Reform)
}

\author{
M. Ilham F. Putuhena \\ Badan Pembinaan Pembangunan Hukum Nasional \\ JI. Mayjen. Sutoyo No. 10 Cililitan Jakarta Timur \\ Email: m.ilham.f.putuhena@gmail.com
}

Naskah diterima: 11 November 2013; revisi: 15 November 2013; disetujui: 20 November 2013

\begin{abstract}
Abstraks
Sebagai negara yang berdasarkan hukum (nomokracy) dan demokrasi, Indonesia juga menerapkan peran negara sebagai negara kesejahteraan (welfare states), yang ternyata tidak mudah dalam pelaksanaannya. Undang-undang sebagai salah satu wajah hukum, ternyata tidak dapat berperan secara maksimal dalam ruang sosial, bahkan peraturan tertulis tersebut membawa masalah baru dalam penataan pembangunan nasional saat ini, sehingga perlu tindakan progresif dalam politik hukum perundang-undangan saat ini. Dengan pendekatan yuridis Normatif, penulis mencoba menempatkan politik hukum dengan cara mempertegas legislasi progresif, langkah-langkah yang harus dilakukan adalah segera melaksanakan Program review perundang-undang sebagai alat evaluasi perundang-undangan saat ini, dan kemudian merubah mekanisme pembahasan rancangan undang-undang di Dewan Perwakilan Rakyat, khususnya dengan mengganti mekanisme Daftar Infentaris Masalah (DIM) untuk meningkatkan efektivitas pembahasan, begitupun dengan penetapkan pembatasan masa berlaku tiap undang-undang untuk mendorong Undang-undang yang progresif.
\end{abstract}

Kata Kunci: politik hukum, legislasi, progresif

As a state based on law (nomocracy) and democracy, Indonesia also implementing role of the state's as a welfare state (welfare states), which it was not easy in implementation. As the one face of law act was not able to play a role that contribute maximally in the social space, The written rules even bring new problems in the structuring of national development at this time, so it needs a progressive action in the legal politics of legislation at this time. With normative juridical approach, authors tried to put in the legal politics by clarifying progressive legislation, the steps that must be done are to immediately implement the legislation review program as a tools of evaluating the current legislation, And then alter the mechanism of Bill discussion in the House of Representatives, Specialy by changing the mechanism of List of Issues (DIM) to increase the effectiveness of the discussion, as well as setting the limitations on the duration of each act, to encourage progressive legislation.

Keywords: politic of law, legislation, progressive 


\section{A. Pendahuluan}

Membahas legislasi tidak terlepas dalam sebuah mendasar konsep Negara Hukum, diindonesia konsepsi Negara Hukum atau "Rechtsstaat" dirumuskan dengan tegas dalam Pasal 1 ayat (3) yang menyatakan, "Negara Indonesia adalah Negara Hukum." Jimly Asshiddiqie menjelaskan bahwa, ${ }^{1}$ negara Indonesia juga disebut sebagai Negara Hukum (Rechtstaat), bukan Negara Kekuasaan (Machtstaat). Di dalamnya terkandung pengertian adanya pengakuan terhadap prinsip supremasi hukum dan konstitusi, dianutnya prinsip pemisahan dan pembatasan kekuasaan menurut sistem konstitusional yang diatur dalam Undang-Undang Dasar, adanya jaminanjaminan hak asasi manusia dalam UndangUndang dasar, adanya prinsip peradilan yang bebas dan tidak memihak yang menjamin persamaan setiap warga negara dalam hukum, serta menjamin keadilan bagi setiap orang termasuk terhadap penyalahgunaan wewenang oleh pihak yang berkuasa.

Dalam paham Negara Hukum yang demikian itu, pada hakikatnya hukum itu sendirilah yang menjadi penentu segalanya sesuai dengan prinsip nomokrasi (nomokracy) dan doktrin 'the Rule of Law, and not of Man'. Dalam kerangka 'the rule of Law' itu, diyakini adanya pengakuan bahwa hukum itu mempunyai kedudukan tertinggi (supremacy of law), adanya persamaan dalam hukum dan pemerintah (equality before the (aw), dan berlakunya asas legalitas dalam segala bentuknya dalam kenyataan praktek (due process of law).

Dalam sisi yang lain Negara juga mempunyai peran dalam melakukan fungsi sebagai alat kemakmuran rakyat, hal ini dikenal dengan konsep negara kesejahteraan. Dalam UUD RI 1945 Negara bertanggung jawab atas kesejahteraan masyarakat berdasarkan pembukaan alinea ke-3 Undang-Undang Dasar Republik Indonesia 1945 (selanjutnya disebut UUD RI 1945) kemudian ditegaskan kembali pada Pasal 33 dan 34 UUD 1945 .

Ide dasar negara kesejahteraan beranjak dari abad ke-18 ketika Jeremy Bentham (1748-1832) mempromosikan gagasan bahwa pemerintah memiliki tanggung jawab untuk menjamin the greatest happiness (atau welfare) of the greatest number of their citizens. Bentham menggunakan istilah 'utility' (kegunaan) untuk menjelaskan konsep kebahagiaan atau kesejahteraan. Berdasarkan prinsip utilitarianisme yang ia kembangkan, Bentham berpendapat bahwa sesuatu yang dapat menimbulkan kebahagiaan ekstra adalah sesuatu yang baik. Sebaliknya, sesuatu yang menimbulkan sakit adalah buruk. Menurutnya, aksi-aksi pemerintah harus selalu diarahkan untuk meningkatkan kebahagian sebanyak mungkin orang. Gagasan Bentham mengenai reformasi hukum, peranan konstitusi dan penelitian sosial bagi pengembangan kebijakan sosial membuat ia dikenal sebagai "bapak kesejahteraan negara" (father of welfare states). ${ }^{2}$ 
Dalam rangka mewujudkan masyarakat yang sejahtera campur tangan Negara atau pemerintah terhadap berbagai aspek kehidupan masyarakat tidak dapat dihindari. Dan campur tangan pemerintah haruslah dirumuskan dalam bentuk hukum atau peraturan perundangundangan yang bersifat memaksa baik peraturan perundangan di tingkat nasional maupun daerah. Dengan demikian dalam praktek penyelenggaraan Negara tidak dapat lepas dari apa yang disebut kebijakan-kebijakan yang dirumuskan dalam Legislasi (peraturan perundang-undangan) sebagai payung hukum dalam mengimplementasikan kegiatan oleh negara.

Membangun kualitas produk legislasi nasional menjadi sangat penting untuk mewujudkan tujuan Negara sebagai negara kesejahteraan (welfare state) sebagaimana diamanatkan dalam konstitusi, sehingga bagai mana cara menghasilkan kualitas legislasi yang progresif menjadi tanggung jawab yang besar bagi aktor negara (DPR,DPD dan Pemerintah).

Kata 'Legislasi' sendiri berasal dari bahasa Inggris legislation. Ditinjau secara kebahasaan maupun dalam khasanah ilmu hukum, 'legislasi' mengandung makna dikotomis, yang bisa berarti (1) proses pembentukan hukum (perundangundangan), dan juga bisa berarti (2) produk hukum (perundang-undangan) ${ }^{3}$

Menurut Aan Eko, ${ }^{4}$ berbagai peraturan perundang-undangan yang mengatur tentang pembentukan undang-udang tersebut ternyata masih belum memenuhi cita negara hukum yaitu pertama, hubungan antara yang memerintah dengan yang diperintah tidak berdasarkan kekuasaan, melainkan berdasarkan suatu norma objektif yang juga mengikat pihak yang memerintah. Kedua, norma objektif atau disebut hukum tidak hanya memenuhi syarat formal namun secara substantif harus adil dan responsif. Tentunya hal ini tidak terlepas dari kualitas suatu undang-undang. Indikator kualitas undang-undang tersebut dapat dilihat dari seringnya pengujian undang-undang ke Mahkamah Konstitusi (MK), dan undangundang itu bisa dijalankan atau tidak.

Pandangan serupa terhadap permasalahan peraturan perundang-undangan juga di sampaikan Wicipto Setiadi ${ }^{5}$ yang kemudian mengambarkan secara sistematis permasalahan dalam pembentukan Undang-Undang antara ada beberapa:

2 Edi Suharto, PhD, "Peta Dan Dinamika Welfare State Di Beberapa Negara: Pelajaran apa yang bisa dipetik untuk membangun Indonesia?", (Makalah disampaikan pada Seminar "Mengkaji Ulang Relevansi Welfare State dan Terobosan melalui Desentralisasi-Otonomi di Indonesia", Institute for Research and Empowerment (IRE) Yogyakarta dan Perkumpulan Prakarsa Jakarta, bertempat di Wisma MM Universitas Gadjah Mada, Yogyakarta 25 Juli 2006)

3 Lihat John M. Echols dan Hassan Shadily menerjemahkan legislation sebagai (1) perundang-undangan, (2) pembuatan undang-undang. John M. Echols dan Hassan Shadily Kamus Inggris Indonesia. (Jakarta: Gramedia, 1995) hlm. 353. Jeremy Bentham dan John L. Austin mengaitkan istilah legislation sebagai "any form of lawmaking". Jeremy Bentham, An Introduction to the Principles of Morals and Legislation. J.H. Burns and H.L.A. Hart (ed.). (Oxford: Clarendon Press, 1996); John L. Austin The Province of Jurisprudence Determined and the Uses of the Study of Jurisprudence, London: Weidenfeld and Nicolson, 1954; Lihat pada Jimly Asshiddiqie, Perihal Undang-Undang. (Jakarta: Konstitusi Press, 2006.) hlm. 31-32

4 Aan Eko Widiarto, "Mengukur Kualitas Legislasi Dalam Perspektif Legisprudence”, (Makalah disampaikan dalam Konfrensi Negara Hukum, Hote Bidakara Tahun 2012,) hlm 3.

5 Wicipto Setiadi, "Mewujudkan Perencanaan Pembentukan Undang-Undang yang Terencana, Terpadu dan Sistematis Kaitannya dengan Konsep Reformasi Regulasi", (Makalah disampaikan dalam Konsultasi Publik Reformasi Regulasi, BAPPENAS, 21 Mei 2013). 
1) Permasalahan Materiil

a) Dasar Konstitusional, terjadi pertentangan antar undang-undang yang dihasilkan dengan UUD RI 1945, biasanya disebabkan oleh proses yang kurang baik sehingga beberapa undang-undang yang baru disahkan lansung digugat di Mahkamah Konstitusi (MK).

b) Keinginan VS Kebutuhan, kebanyakan pengajuan rancangan undang-undang masih sebatas keinginan dari inisiatornya bukan kebutuhan permasalahan yang seharusnya diatur melalui undangundang, paradigman pembentukannya menganggap pengaturan harus diatur diundang-undang biar kuat padahal tidak semua pengaturan harus diatur di undang-undang.

c) Tumpang tindih, banyak peraturan perundang-undangan yang tumpang tindih secara vertikal dan horisontal, terkadang undang-undang dikesampingkan oleh peraturan dibawahnya atau antara setingkat undang undang itu sendiri.

d) Daya laku VS daya guna, beberapa undang-undang yang dihasilkan walaupun populis dimasyarakat tetapi ternyata pada pelaksanaanya tidak maksimal dalam penegakannya, seperti UU anti pornografi dan porno aksi. Mempertimbangkan realitas sosail harusnya menjadi pertimbangan penting dalam pembentukan UU.

e) Perkembangan masyarakat dan Iptek cepat berubah, perkembangan tersebut menyebabkan banyak undang-undang yang tidak dapat diaplikasikan dalam menjawab masalah sosial dimasyarakat. Perkembangan masyarakat dan teknologi sangat cepat sehingga undang-undang yang dibentuk kadang tidak sesuai alagi dengan kondisi masyarakat.

2) Permasalahan Formal/Proses Pembentukan

a) Pra Legislasi, proses sebelum pembahasan undang-undang.

i) Kualitas Penelitian/Pengkajian, kualitas dalam Penelitian/Pengkajian seharusnya menjadi bahan utama dalam pengaturan substansi undang-undang, tetapi ternyata masih banyak penelitian yang belum dijadikan bahan dalam pembahasan undang-undang atau pada pembentukan naskah akademik.

ii) Penentuan Prioritas dalam Prolegnas, prolegnas belum didorong sebagai perencanaan utama dalam legislasi, sehingga keinginan pembentukan undang-undang tidak sesuai dengan kemampuan pembentuk undangundang. List prolegnas dan realisasi masih terjadi ketimpangan yang cukup tinggi, dari 247 RUU yang disetujui dalam Prolegnas 2010-1014, yang sudah disahkan baru 48 RUU (Diluar RUU daftar kumulatif terbuka).

iii) Kualitas Naskah Akademik, naskah akademik mulai diutamkan kegunaanya setelah diatur undang-undang no 12 tahun 2011 tentang permbentukan peraturan prundang-undangan, sampai saat ini belum ada lembaga yang memantau kualitas Naskah Akademik, sehingga semua naskah akademik bisa dibuat oleh siapapun dan lembaga manapun akan tetapi menilai kualitas Naskah Akademik menjadi bahan untuk pembentukan undang-undang belum ada. 
iv) Penyusunan RUU, masih kurangnya pendekatan multisektor dalam penyusunan RUU, sehingga metode penyusunan RUU berpotensi terjadinya konflik antar lembaga maupun dengan masyarakat.

v) Partisipasi masyarakat, partisipasi masyarakat belum mendapatkan jaminan hukum yang lebih baik, khususnya mekanisme dalam menindaklanjuti aspirasi masyarakat dan hasil dari tindaklanjut aspirasi tersebut, pembangunan mekanisme komunikasi atau aspirasi seharusnya berjalan dua arah.

b) Proses Legislasi

1) Mekanisme Pembahasan, mekanisme pembahasan saat ini kurang efektif diantaranya dengan menggunakan pembagian fraksi dalam DPR pada saat pembahasan undang-undang dengan pemerintah. Belum lagi tidak ada pembatasan waktu yang cukup ketat dalam pembahasan undang-undang.

2) Partisipasi Masyarakat, ruang masyarakat dalam berpartisipasi sebaiknya didorong dengan menggunakan teknologi internet atau sidang lansung, mekanisme ini belum menjadi standar kewajiban bagi DPR untukmembuka proses pembahasan RUU.

c) Pasca Legislasi

1) Mekanisme Diseminasi, minimnya informasi dan penjelasan dalam perundang-undangan membutuhkan mekanisme diseminasi untuk menyebarkan informasi dan rasionalisasi perundang-undangan.

2) Budaya Hukum masyarakat, pluralisme hukum diindonesia belum merubah pola pendekatan dalam membangun budaya hukum, yang masih mengandalkan pendekatan formal, sehingga media informal khususnya adat istiadat, belum maksimal untuk menjadi alat membangun budaya hukum

3) Permasalahan Kelembagaan

1) Ego sektoral lembaga, mengakibatkan tumpang tindih peraturan dan menimbulkan ketidak pastian hukum.

2) Ego kedaerahan, menyebabkan negara tanpa desain, sehingga potensi perpecahan antara daerah menjadi sebuah permasalahan yang baru dalam otonomi daerah saat ini, khusunya dalam pengaturan peraturan didaerah.

Masalah legislasi juga dipaparkan oleh BAPPENAS yang telah mengidentifikasi bahwa permasalahan implementasi peraturan di Indonesia antara lain adalah: ${ }^{6}$

a) Multi tafsir. Ketidak jelasan dalam pengaturan menyebabkan ketidak pastian hukum.

b) Potensi konflik, antar materi perundangundangan.

c) Tumpang tindih, kewenangan. Pengaturan kewenangan yang tidak teratur.

d) Ketidak sesuaian asas. Peraturan menteri terkadang mengatur melebihi peraturan perundang-undangan.

Direktorat Analisa Peraturan Perundang-Undangan ,BAPPENAS, "Paper Penelitian Pemetaan Hasil Identifikasi Terhadap Undang-Undang Sektor Yang Berpotensi Bermasalah" (Makalah disampaikan pada Workshop Koordinasi Strategis Analisa Peraturan Perundang-Undangan, Direktorat Analisa Peraturan PerundangUndangan ,BAPPENAS, Jakarta 5 Desember 2012), hlm. 16. 
e) Lemahnya efektivitas implementasi.

f) Tidak harmonis/tidak sinkron antar peraturan perundang-undangan secara Vertikal amupun horisontal.

g) Tidak ada dasar hukumnya.

h) Tidak adanya aturan pelaksanaannya, padahal sudah diamanahkan dalam undangundang tetapi peraturan pelaksan belum juga di bentuk.

i) Tidak konsisten. Menunjukkan ketidak sesuaian dalam perencanaan penataan hukum.

j) Menimbulkan beban yang tidak perlu, baik terhadap kelompok sasaran maupun kelompok yang terkena dampak

Dari hasil kajian BAPPENAS, penyebab permasalahan tersebut antara lain disebabkan oleh: ${ }^{7}$

a) Perumusan regulasi yang tidak sistematik.

b) Tidak jelasnya acuan tools regulasi serta tidak memperhatikan standar internasional yang telah menjadi best practices dan common practices terkait principles of good regulations.

c) Pendekatan regulasi yang bersifat sektoral atau dipengaruhi kepentingan ego sektoral.

d) Ketidak jelasan batas-batas kewenangan kelembagaan termasuk mekanisme koordinasinya.

e) Keterbatasan kapasitas sumber daya manusia yang terkait dengan perumusan regulasi.

f) Kurang memadainya proses konsultasi public. g) Kurangnya persiapan dalam implementasi regulasi.

h) Kurangnya dilakukan cost and benefit analysis.

Sehingga kalau mencoba memotret lebih luas permasalahan hukum ternyata bukan hanya pada permasalahan penegakan hukum atau perilaku masyarakat, tetapi ternyata permasalah terdapat pada aturan hukum itu sendiri, dan pabila aturan hukum yang menjadi masalah maka masyarakatlah yang akan menjadi objek bagi hukum bukan subjek bagi hukum itu sendiri.

Menurut Satjipto Rahardjo, ${ }^{8}$ hukum adalah untuk manusia, sedang pada ilmu hukum praktis manusia adalah lebih untuk hukum dan logika hukum. disinilah salah satu prinsip hukum progresif. Oleh karena ilmu hukum progresif lebih mengutamakan manusia, maka ilmu hukum progresif tidak bersikap submisif atau tunduk begitu saja terhadap hukum yang ada melainkan bersikap kritis.

Dalam konsep hukum progresif, pembaruan hukum di Indonesia bertujuan untukmembentuk suatu hukum nasional, bukan semata-mata bermaksud untuk mengadakan pembaruan (ansich), akan tetapi juga diwujudkan menuju pembaruan hukum yang berwatak progresif, yang mana kebijakan pembaruan hukum merupakan konkretisasi dari sistem nilainilai yang berlaku dalam masyarakat. Suatu keadaan yang dicita-citakan adalah adanya kesesuaian antara hukum dengan sistem-sistem nilai tersebut. Konsekuensinya adalah bahwa 
perubahan pada sistem nilai-nilai harus diikuti dengan pembaruan hukum, atau sebaliknya. ${ }^{9}$

Mendorong proses pembaruan hukum demi terwujudnya kesadaran baru-tanpa bisa diingkari-merupakan bagian dari proses politik yang progresif dan reformatif. Di sini hukum dapat difungsikan sebagai suatu alat pembaharuan masyarakat (tool of social engineering), entah yang diefektifkan lewat proses-proses yudisial atau yang diefektifkan melalui proses legislatif. ${ }^{10}$ Dalam pendekatan penulis gagasan tersebut dilakukan dalam proses legislasi diindonesia.

Untuk memahami Makna Hukum Progresif itu sendiri Soetandyo Wignjosoebroto, ${ }^{11}$ mencoba menjelaskan secara singkat hukum progresif. Secara harfiah menurut kamus umum, kata 'progresif' itu mengacu ke artinya sebagai karakter suatu variabel yang punya kecenderungan kuat untuk selalu bergerak ke depan, meninggalkan posisinya yang semula. Diartikan demikian, kata 'progresif' bolehlah dilawankan dengan istilah antonim 'regresif', ialah kecenderungan untuk bergerak mundur ke statusnya yang dulu-dulu; atau boleh juga dilawankan dengan kata 'konservatif', ialah kecenderungan untuk bertahan pada statusnya yang telah ada kini ini. Maka mengartikan 'progresif' sebagai lawan 'regresif' atau 'konservatif', bolehlah saya mengajuk dan memformulasi ulang apa yang dimaksud Prof Tjip dengan 'hukum progresif' itu, yang tak lain daripada paradigma hukum baru yang hendak menjawab permasalahan mutakhir yang tak lagi dapat diselesaikan berdasarkan paradigma lama, ialah paradigma positivisme.

Sehingga Mendorong Legsilasi Progresif merupakan gagasan yang mencoba menempatkan posisi pembentukan undang-undang yang lebih berkualitas dan efektif dimasyarakat. Produl Legislai bukan menjadi permasalahan baru tetapi menjadi solusi bagi negeri ini.

\section{B. Permasalahan}

Dari latar belakang yang telah di paparkan sebelumnya maka terdapat permasalahan yang hendak dijawab dalam kajian ini yaitu:

1. Bagaimanakah aspek yang mempengaruhi Legislasi diindonesia saat ini?

2. Bagaimanakah Langkah yang harus dilakukan dalam mendorong Legislasi yang Progresif?

\section{Metode Penelitian}

Penelitian ini menggunakan metode penelitian yuridis Normatif, ${ }^{12}$ dimana Data

9 Ibid.

$10 \quad$ Ibid. Hlm. 19.

11 Soetandyo Wignjosoebroto, Prof Tjip dan Ajaran Hukum Progresifnya: Sebuah Pengantar Ringkas (Jakarta: Huma, 2011), hlm. viii.

12 Soerjono Soekanto \& Sri Mamudji, menyebutkan dengan istilah metode penelitian hukum normatif atau metode penelitian hukum kepustakaan (Soerjono Soekanto \& Sri Mamudji, Penelitian Hukum Normatif (Suatu Tinjauan Singkat),(Jakarta: Rajawali Pers, 2001,) hlm. 13-14.); Soetandyo Wignjosoebroto, menyebutkan dengan istilah metode penelitian hukum doktrinal (Soetandyo Wignjosoebroto, Hukum, Paradigma Metode dan Dinamika Masalahnya, Editor : Ifdhal Kasim et.al. (Jakarta, Elsam dan Huma, 2002), hlm. 147); Sunaryati Hartono, menyebutkan dengan istilah metode penelitian hukum normatif (C.F.G. Sunaryati Hartono, Penelitian Hukum Di Indonesia Pada Akhir Abad Ke-20 (Bandung: Alumni, 1994), hlm. 139) dan Ronny Hanitjo Soemitro, menyebutkan dengan istilah metode penelitian hukum yang normatif atau metode penelitian hukum yang doktrinal (Ronny Hanitijo Soemitro, Metodologi Penelitian Hukum dan Jurimetri, (Jakarta:Cetakan Kelima, Ghalia Indonesia, 1994), hlm. 10). 
diperoleh dari studi kepustakaan akan dianalisis secara deskriptif kualitatif. Analisis deskriptif kualitatif yaitu metode analisis data yang mengelompokkan dan menyeleksi data yang diperoleh menurut kualitas dan kebenarannya, kemudian dihubungkan dengan teori-teori, asas-asas, dan kaidah-kaidah hukum yang diperoleh dari studi kepustakaan sehingga diperoleh jawaban atas permasalahan yang dirumuskan.

\section{Pembahasan}

Berdasarkan segi paradigmatik, terdapat dua landasan pokok yang harus menjadi pilar dalam pelaksanaan pembangunan politik hukum nasional, yaitu landasan Idiil dan landasan operasional: ${ }^{13}$

Landasan idiil merupakan norma dasar kehidupan berbangsa dan bernegara, yaitu hukum yang berwatak Pancasila. Sedangkan landasan operasional terdiri atas, pertama, hukum yang adil dan mensejahterakan, yaitu hukum harus dijadikan sarana pembaruan untuk menyejahterakan masyarakat, oleh karena itu untuk membuat hukum yang adil dan menyejahterakan harus harmonis dan menyesuaikan dengan konsep negara kesejahteraan; kedua, hukum yang memperkuat demokrasi, yaitu membangun hukum yang memperkokoh demokrasi harus dilandasi oleh konsep atau pola pikir mengenai bagaimana membumikan idealisme demokrasi yang berwajah keadaban ke dalam kehidupan politik praktis, oleh karena itu perlu fondasi hukum yang mencerminkan demokrasi yang rasional dengan muatan moral yang kental; ketiga, hukum yang melindungi HAM, keempat, hukum yang memperkukuh NKRI, hal ini menjadi Jandasan dalam merancang (merencanakan, membahas, merumuskan, memutuskan dan menetapkan) berbagai produk-produk hukum dengan segala tata urutan perudangan dalam sistem hukum nasional serta mengokohkan politik hukum negara terhadap pemantapan NKRI; kelima, hukum yang berbhineka tunggal ika, yaitu hukum nasional yang akan diwujudkan harus memperhatikan perbedaan latar belakang sosial budaya dan perbedaan kebutuhan hukum yang dimiliki oleh kelompok tertentu, dengan tetap berpedoman pada Wawasan Nusantara dan tetap mengutamakan persatuan dan kesatuan bangsa; dan keenam, hukum yang melindungi bangsa dan tumpah darah Indonesia.

Landasan pokok tersebut hendaknya menjadi dasar dalam pelaksanaan politik hukum nasional, karena politik hukum sangat menentukan arah kebijakan pembangunan nasional secara keseluruhan yang akan dilaksanakan dalam suatu periode tertentu. Politik hukum pada dasarnya merupakan pemikiran yang menjadi dasar campur tangan negara melalui alat perlengkapan negara (pemerintah, DPR, dan sebagainya) pada hukum. Campur tangan negara dengan alat perlengkapannya pada hukum, dalam hal: pertama, Penciptaan Hukum, yaitu negara berkewajiban memelihara keadilan dan ketertiban; kedua, Pelaksanaan Hukum, yaitu negara berkewajiban mengadakan alat-alat perlengkapan negara yang bertugas melaksanakan atau menegakkan hukum menurut cara tertentu yang ditentukan oleh negara, antara lain melalui pengadilan; dan 
ketiga, Perkembangan Hukum, yaitu hukum disusun berdasarkan kesadaran hukum masyarakat. Negara berusaha mempengaruhi perkembangan kesadaran hukum masyarakat, sehingga negara mempengaruhi perkembangan hukum: ${ }^{14}$

Sehingga legislasi menjadi pintu utama dalam menjalankan politik hukum nasional, sebagai negara yang menjunjung tinggi hukum (nomokrasi) dan demokrasi dalam penyelenggaraan negara.

Menurut Soetandyo Wignjosoebroto, ${ }^{15}$ terdapat tiga karakteristik yang melekat, sine qua non, dalam konsep rechtsstaat, ketika harus diterapkan dalam kehidupan bernegara, yaitu: pertama, bahwa apa yang disebut 'hukum' dalam negara hukum itu harus dibentuk dalam wujudnya yang positif. Demi kepastian berlakunya di alam yang objektif (yang dalam bahasa falsafah positivisme Perancis disebut 'alam positif'), hukum mestilah dibentuk ke dalam preskripsi-preskripsi, ialah rumus-rumus tertulis yang mendalilkan adanya hubungan sebab akibat antara suatu perbuatan hukum atau peristiwa hukum tertentu dengan akibat hukumnya; kedua, apa yang disebut hukum (yang telah selesai dalam bentuknya yang preskriptif-positif itu, dan boleh disebut ius constitutum atau lege alias undang-undang itu) harus merupakan hasil proses kesepakatan kontraktual antara golongan-golongan partisan dalam suatu negeri, langsung ataupun melalui wakil-wakilnya, melalui suatu proses yang disebut 'proses legislasi'; ketiga, hukum yang telah diwujudkan dalam bentuk undangundang (berikut undang-undang yang paling dasar yang disebut Undang-Undang Dasar) dan bersifat kontraktual itu akan mengikat seluruh warga bangsa secara mutlak, mengalahkan aturan-aturan normatif macam apapun, yang lokal ataupun yang sektarian, namun yang belum disepakatkan melalui proses legislatif agar diberlakukan sebagai bagian dari hukum nasional.

Tiga karakteritik pokok berimplikasi bahwa hukum (undang-undang nasional hasil kesepakatan legislatif) itu berkedudukan tertinggi. Konsep rechtsstaat tersebut sekaligus juga menyatakan asas bahwa hukum undangundang nasional itu merupakan hukum yang berstatus paling tinggi (mengatasi norma macam apapun yang berlaku secara informal dalam masyarakat). Dinyatakan di dalam bahasa Belanda, rechtsstaat itu boleh juga terbaca sebagai singkatan dari de hoogste rechtsstaat, atau yang dikatakan di dalam bahasa Inggris sebagai the supreme state of law, yang apabila diterjemahkan balik ke dalam bahasa Indonesia tidak lagi berarti 'negara hukum', melainkan 'status supremasi hukum perundang-undangan nasional', yang akan mengikat siapapun yang berada di teritori berlakunya hukum nasional hasil kerja legislasi itu, baik yang awam biasa maupun yang mengemban jabatan di struktur kekuasaan ${ }^{16}$. Sehingga legislasi juga tidak bisa terlepas dari politik hukum negara.

Abdul Hakim G Nusantara dan Arief Budiman mengemukakan konsep yang dapat digunakan

\footnotetext{
14 Ibid., Hal 67.

15 Soetandyo Wignjosoebroto, Negara Hukum Dan Permasalahan Akses Keadilan Di Negeri-Negeri Berkembang Pasca-Kolonial, (Makalah disampaikan dalam Konferensi Dan Dialog Nasional, Jakarta, Hotel Bidakara 9-10 Oktober 2012).

16 Ibid., hlm 3.
} 
untuk memahami perspektif pemikiran politik hukum. Menurut Abdul Hakim G Nusantara, ${ }^{17}$ politik hukum nasional secara harfiah diartikan sebagai kebijakan hukum (legal policy) yang hendak diterapkan atau dilaksanakan secara nasional oleh suatu pemerintahan negara tertentu. Politik hukum nasional bisa meliputi: 1) pelaksanaan ketentuan hukum yang telah ada secara konsisten; 2) pembangunan hukum yang intinya adalah pembaruan terhadap ketentuan hukum yang telah ada dan yang dianggap usang, dan penciptaan ketentuan hukum baru yang diperlukan untuk memenuhi tuntutan perkembangan yang terjadi dalam masyarakat; 3) penegasan fungsi lembaga penegak atau pelaksana hukum dan pembinaan anggotanya; dan 4) meningkatkan kesadaran hukum masyarakat menurut persepsi kelompok elit pengambil kebijakaan.

Keempat faktor tersebut menjelaskan secara gamblang wilayah kerja politik hukum yang mencakup teritorial berlakunya politik hukum dan proses pembaruan dan pembuatan hukum, dengan sikap kritis terhadap hukum yang berdimensi ius constitutum dan menciptakan hukum yang berdimensi isu constituendum. ${ }^{18}$ Mengacu pendapat Arief Budiman, pemerintah dalam mengeluarkan kebijakan tidak sematamata ditentukan oleh pemerintah secara mandiri, tetapi tetap ditentukan oleh "kondisi

Tabel 1. Sifat Kebijakan Pemerintah Berdasarkan Kondisi Struktural dan Corak Penguasa

\begin{tabular}{|c|l|l|}
\hline Aspek & \multicolumn{1}{|c|}{ Uraian } & \multicolumn{1}{|c|}{ Sifat } \\
\hline \multirow{3}{*}{ Konteks } & $\begin{array}{l}\text { Kondisi Struktural; Pakta Dominasi, Pengaturan Kekayaan, } \\
\text { Hubungan Sosial, Ekonomi dan Politik dari Kekuatan } \\
\text { Produksi, baik secara Nasional maupun Internasional. }\end{array}$ & $\begin{array}{l}\text { Feodalisme, Kapitalisme, } \\
\text { Sosialisme, dan sebagainya. }\end{array}$ \\
\hline \multirow{3}{*}{ Pelaksana } & $\begin{array}{l}\text { Pemerintah; Aparat Politik \& Birokrasi, Aspek Personel } \\
\text { dari Negara }\end{array}$ & $\begin{array}{l}\text { Pra-Birokratik, Birokratik, } \\
\text { Post Birokratik }\end{array}$ \\
\cline { 2 - 3 } & Rezim; Sistem Politik, cara Penyelenggaraan Kekuasaan & $\begin{array}{l}\text { Totaliter, Otoriter, Semi- } \\
\text { Demokrasi, Demokrasi }\end{array}$ \\
\hline \multirow{2}{*}{ Hasil } & Kebijakan Publik & Represif, Otonom, Responsif ${ }^{20}$ \\
\hline
\end{tabular}

Sumber: Arief Budiman, Teori Negara; Negara, Kekuasaan dan Ideologi (Jakarta: Gramedia Pustaka Utama 1997).

17 Abdul Hakim G Nusantara, "Politik Hukum Nasional" (Makalah pada Karya Latihan Bantuan Hukum (Kalabahu), YLBHI \& LBH Surabaya, September 1985) sebagaimana dikutip dalam Imam Syaukani \& A. Ahsin Thohari, "Dasar-Dasar Politik Hukum" (Jakarta,Raja Grafindo Persada, 2006), hlm. 30-31.

$18 \quad$ Ibid, hlm. 31.

19 Ditambahkan oleh Pusat Studi Kebijakan Hubungan Pusat dan Daerah, Pembangunan Hukum Dan Konflik Undang-Undang Bidang Sektoral (Jakarta: PSHK, Tahun 2009,) hlm. 18., yang dikutip dari Philippe Nonet \& Philip Selznick, Law \& Society in Transition: Toward Responsive Law (London: Harper \& Row, Publishers New York, Hagerstown, San Francisco, 1978), hlm. 22.

20 Ibid. hlm. 16. 
struktural"21 dari pemerintahan sendiri. Kebijakan juga ditentukan oleh rezim yang ada. Jadi kebijakan dalam sebuah rezim yang otoriter akan mengalami perubahan dibawah rezim yang demokrasi, namun apakah perubahan itu bersifat substansial atau tidak itu persoalan lain.

Unsur dominan dalam suatu perubahan kebijakan adalah kondisi struktural, karena kebijakan publik merupakan hasil interaksi dari kondisi struktural (proses politik antara pemerintah yang berkuasa dengan dan proses politik yang ditempuh) yang ada. Faktor dominan dari kondisi struktural yang mempengaruhi kebijakan tergantung pula dengan jenis kebijakannya. Untuk kebijakan tertentu mungkin kondisi struktural yang paling dominan, tetapi untuk lain kebijakan mungkin unsur pemerintah atau proses politiknya yang menjadi faktor dominan. Salah satu bentuk kebijakan publik adalah perturan perundangundangan atau legislasi.
Studi hukum dengan objek kajian legislasi semacam ini masuk dalam lingkup IImu pengetahuan perundang-undangan (Gesetzgebungswissenschaft) - yang merupakan bagian dari Hukum Tata Negara - khususnya masuk dalam ranah ilmu perundang-undangan (Gesetzgebungslehre). ${ }^{22}$ Menurut Burkhardt Krems, ilmu pengetahuan perundang-undangan (Gesetzgebungswissenschaft) - sebagai disiplin ilmu yang relatif baru - merupakan ilmu yang interdisipliner yang berhubungan dengan ilmu politik dan sosiologi. Ilmu perundangundangan (Gesetzgebungslehre) berorientasi pada perbuatan dalam pembentukan peraturan perundang-undangan dan bersifat normatif. ${ }^{23}$

Dengan posisi bahwa studi tentang legislasi ini pada dasarnya merupakan studi hukum dalam ranah ilmu perundang-undangan (Gesetzgebungslehre), namun demikian ia tidak dapat dipisahkan dari studi politik dan sosiologi. Mengkaji legislasi dalam ranah ilmu perundang-

21 Kondisi Struktural dari negara; meliputi pakta dominasi dari kekuatan-kekuatan masyarakat yang ada dengan negara di mana pengaturan kekayaan-yakni siapa yang mendapat apa dan berapa banyak, serta cara-cara mendapatkan kekayaan itu diatur. Dengan lain perkataan, kondisi struktural meliputi aspek-aspek hubungan sosial, politik dan ekonomi. Perlu dicatat juga bahwa dalam konsep kondisi struktural ini, termasukjugakekuatankekuatan internasional yang berpengaruh pada pengaturan kekayaan dan pakta dominasi di sebuah negara tertentu. Bantuan ekonomi dan militer dari negara-negara adidaya dan lembaga-lembaga keuangan internasional untuk mendukung sebuah negara tentunya merupakan kondisi yang memperkokoh kekuasaan negara yang dibantu. Lihat dalam: Arief Budiman. Teori Negara; Negara, Kekuasaan dan Ideologi (Jakarta: Gramedia Pustaka Utama, 1997), hlm. 90-93).

22 A. Hamid S. Attamimi "Ilmu Perundang-undangan (Gesetzgebungslehre) dan Teori Perundang-undangan (Gesetzgebungstheorie) serta pengajarannya di Fakultas Hukum". 1993, Dalam Maria Farida Indrati Soeprapto, Ilmu Perundang-undangan Dasar-dasar dan Pembentukannya. (Yogyakarta: Kanisius, 1998), hlm. xvii. Lihat juga Jazim Hamidi dan Budiman N.P.D. Sinaga, Pembentukan Peraturan Perundang-undangan dalam Sorotan: UndangUndang Nomor 10 Tahun 2004 Tentang Pembentukan Peraturan Perundang-undangan Dilengkapi dengan Analisa Kritis. (Jakarta: Tatanusa, 2005. Budiman N.P.D. Sinaga, Ilmu Pengetahuan Perundang-udangan. (Yogyakarta:UUI Press, 2005.) hlm. 4-5, menyebutkan bahwa Ilmu Pengetahuan Perundang-undangan (Gesetzgebungswissenschaft) merupakan suatu ilmu relatif baru yang berkembang di Eropa Kontinental, terutama di negara-negara berbahasa Jerman pada tahun tujuh puluhan. Sementara itu, di negara-negara common law ilmu ini kurang bahkan tidak berkembang. Meski kurang bahkan tidak berkembang, istilah ini di Inggris dinamakan Science of Legislation.

23 Ibid. hlm. 2. 
undangan (Gesetzgebungslehre), niscaya harus menerima suatu kenyataan bahwa legislasi, meski berpedoman pada hukum, pada dasarnya merupakan pencerminan dari proses yang terjadi dalam kehidupan sosiopolitik (sociopolitical life). ${ }^{24}$

Konfigurasi politik demokratis adalah suatu susunan kekuatan/kekuasaan politik yang membuka peluang bagi potensi rakyat secara maksimal untuk berpartisipasi dalam menentukan kebijakan negara, oleh karenanya, dalam proses legislasinya akan memberikan peranan besar dan partisipasi penuh kelompokkelompok sosial atau pun individu-individu dalam masyarakat. ${ }^{25}$ Dalam konfigurasi politik yang demokratis, pemerintah, lembaga perwakilan rakyat, dan partai politik merupakan lembaga yang harus melaksanakan kehendakkehendak masyarakatnya dengan cara merumuskan kebijakan secara demokratis dan bekerja secara proposional, dan dunia pers dapat melaksanakan fungsinya dengan bebas tanpa ancaman pembredelan. ${ }^{26}$ Perumusan kebijakan yang demokratis niscaya akan melahirkan hukum dengan tipe responsif.

\section{Aspek Berpengaruh Dalam Proses Legislasi}

Bivitri Susanti ${ }^{27}$ memandang ada dua aspek yang berpengaruh dalam proses legislasi, yaitu: pertama, kapasitas personal para wakil rakyat; dan kedua, kapasitas dukungan kelembagaan wakil rakyat. Menurut pendapat Daniel Dhakidae, kapasitas personal wakil rakyat dapat dilihat dari kapasitasnya dalam mengolah dan mengeksekusi the power of speech yang dimilikinya. Yang pertama adalah political sensibility (kepekaan politik), yakni “... suatu kemampuan memahami, menghayati dan memberikan suatu compassion terhadap persoalan, pergumulan dan nasib suatu bangsa dan konstituen yang diwakilinya." Agar kualitas ini dapat berfungsi optimal, ia harus didukung oleh sebuah kemampuan dasar yang khas yakni technical ability (kemampuan teknis) yang dimaknai sebagai "pengetahuan tentang dan kesadaran akan tanggung jawab seorang anggota dewan tentang hak dan kewajibannya." Ada dua unsur penting dalam kualitas kemampuan teknis ini yaitu; pengetahuan tentang hak dan kewajiban; dan kesadaran akan ethos, etika dan etiket sebagai wakil rakyat. Dua kualitas pokok 
tersebut harus difasilitasi oleh kemampuan wakil rakyat untuk menjaring informasi, menggodoknya dan kemudian memprosesnya dalam pembuatan kebijakan. Kualitas terakhir ini disebut dengan kemampuan metoda. Kedua, kapasitas dukungan kelembagaan wakil rakyat, yang terkait dengan manajemen kelembagaan DPR.

Pasal 1 ayat (3) Undang Undang Dasar Negara Republik Indonesia 1945 (UUD 1945) menyatakan bahwa "Negara Indonesia adalah negara hukum". Konsekuensi dari pernyataan tersebut adalah setiap tindakan yang dilakukan oleh negara/pemerintah dalam rangka penyelenggaraan tugas kenegaraan/ pemerintahan harus berdasarkan hukum dan memberikan kepastian hukum. Kepastian hukum dapat diwujudkan melalui peraturan perundang-undangan yang sederhana dan tertib, dengan didukung penerapan hukum yang baik serta penegakan peraturan perundangundangan yang tegas dan imparsial/tidak memihak.

Di bidang perundang-undangan, pada saat ini terdapat kecenderungan pembentukan peraturan perundang-undangan secara berlebihan tanpa melihat dan memperhatikan arah dan prioritas pembangunan nasional. Hal ini masih ditambah dengan rendahnya kualitas sebagian besar peraturan perundang-undangan baik pusat maupun daerah, yang tercermin pada banyaknya peraturan perundang-undangan yang konflik, multitafsir, inkonsisten dan tidak operasional, baik yang setingkat maupun dengan peraturan perundang-undangan yang lebih tinggi.

Peraturan perundang-undangan pada dasarnya merupakan dasar acuan dalam berperilaku, baik bagi penyelenggara negara maupun bagi masyarakat, termasuk para pelaku ekonomi. Untuk itu, peraturan perundang-undangan selayaknya dirumuskan dengan cara yang sederhana, jelas, tegas dan konsisten sehingga mudah dipahami dan dioperasionalkan. Demikian pula peraturan perundang-undangan, sebaiknya tidak dalam jumlah yang terlalu banyak, hal ini dimaksudkan agar tidak menyulitkan setiap pihak untuk menerapkan dan mematuhinya. Hanya dengan peraturan perundang-undangan yang sederhana dan tertib, maka kepastian hukum dapat terwujud sehingga mampu membangun iklim kerja yang kondusif bagi pencapaian kinerja yang lebih baik.

Kuantitas peraturan perundang-undangan yang terlalu banyak dan kualitas yang buruk disamping mengakibatkan rendahnya tingkat kepatuhan juga membawa konsekuensi sosial ekonomi yang relatif tinggi. Bappenas memberikan penjelasan terhadap konsekuensikonsekuensi tersebut di antaranya sebagai berikut: ${ }^{28}$

1) Kinerja penyelenggaraan negara menjadi kurang optimal. Hal ini bukan semata-mata diakibatkan karena kapabilitas sumber daya manusia, atauminimnyainfrastruktur, namun

28 Badan Perencanaan Pembangunan Nasional (Bappenas), "Pedoman Penerapan Reformasi Regulasi" (Reformasi Regulasi, Bappenas, Jakarta 24 Nopember 2011). 
juga karena peraturan perundang-undangan yang menjadi dasar operasionalnya belum mendukung pencapaian kinerja dengan baik.

2) Rasa aman dalam bekerja. Bagi aparatur pemerintah, mengimplementasikan peraturan perundang-undangan dengan kuantitas yang banyak dan dengan kualitas yang kurang baik (konflik, inkonsisten, multitafsir dan tidak operasional) meningkatkan risiko dalam bekerja. Dalam sistem peraturan perundang-undangan yang diwarnai konflik, inkonsisten, dan multitafsir, untuk mematuhi peraturan perundang-undangan yang satu berarti dimungkinkan melanggar peraturan perundang-undangan yang lain. Semakin banyak konflik peraturan perundangundangan yang dihadapi berarti semakin banyak kemungkinan pelanggaran yang dilakukan dan semakin tinggi risiko yang dihadapi. Meningkatnya risiko seperti ini tidak memberikan rasa aman dalam bekerja.

3) Masyarakat membayar lebih dari pada yang seharusnya. Dalam berbagai bidang, peraturan perundang-undangan menjadi dasar hukum dari berbagai jenis pungutan resmi yang dilakukan oleh pemerintah/ pemerintah daerah. Namun demikian, banyak dari peraturan perundang-undangan terkait pungutan tersebut yang tidak memiliki landasan kuat atau sebenarnya sudah tidak diperlukan lagi, akan tetapi masih efektif dan belum dicabut sehingga masyarakat membayar pungutan secara berlebihan tanpa ada manfaat yang dapat diambil. Peraturan perundang-undangan yang demikian hanya memberikan beban yang berlebihan kepada masyarakat.

4) Inefisiensi anggaran: biaya investasi, implementasi dan penegakan hukum. Kuantitas peraturan perundang-undangan yang berlebihan merupakan beban bagi APBN/APBD, baik pada saat pembentukannya maupun pada saat implementasi maupun penegakannya. Inefisiensi terjadi ketika peraturan perundang-undangan yang dioperasionalkan ternyata tidak memberi manfaat bagi masyarakat luas karena alasan tertentu, misalnya bertentangan dengan peraturan perundang-undangan yang lebih tinggi, duplikasi, atau tidak operasional.

5) Menurunnya minat investasi, terutama Foreign Direct Investment (FDI). Kuantitas peraturan perundang-undangan yang terlalu banyak dan kualitas peraturan perundang-undangan yang kurang baik mengakibatkan tiadanya kepastian hukum. Bagi investor, tiadanya kepastian hukum merupakan hambatan besar karena investor tidak memperoleh jaminan atas investasi yang dilakukannya. Akibatnya investor lebih menahan diri untuk melakukan investasi atau mengalihkan investasinya di negara lain yang lebih mampu memberikan kepastian hukum dan jaminan atas investasinya.

6) Hilangnya kesempatan dan lapangan kerja. Kuantitas peraturan perundang-undangan yang terlalu banyak dan kualitas peraturan perundang-undangan yang kurang baik mengakibatkan para investor kurang berminat untuk menanamkan investasinya. Rendahnya investasi yang merupakan 
penggerak aktivitas perekonomian ini pada saatnya mengakibatkan hilangnya kesempatan dan lapangan kerja terutama tenaga kerja lokal.

7) Hilangnya kesempatan untuk melakukan program pembangunan lain: pengentasan kemiskinan, kesehatan, dan sebagainya. Dengan hilangnya kesempatan dan lapangan kerja tersebut, maka hilang pula kesempatan bagi masyarakat untuk meningkatkan atau mengejar taraf kehidupan yang lebih baik. Dampak lebih lanjut yang terjadi adalah terhambatnya berbagai kegiatan yang dimaksudkan untuk meningkatkan kesejahteraan masyarakat.

Untuk mengatasi permasalahan tersebut dan upaya mewujudkan kepastian hukum serta mendorong kinerja pembangunan yang lebih baik dibutuhkan langkah-langkah luar biasa (extraordinary action) berupa reformasi regulasi. Bukan hanya Reformasi tetapi sebuah langkar Legislasi yang Progresif.

\section{Langkah Reformasi Legislasi Progresif}

Beberapa langkah-langkah yang perlu dilakukan dalam mendorong Legislasi yang Progresif adalah:

\section{a. Review Legislasi Nasional,}

Review legislasi nasional dilakukan untuk mengetahui undang-undang apa saja yang selama ini benar-benar sebagai living law (undang-undang yang hidup) atau mana sebenarnya undang-undang yang termasuk dalam undang-undang bersifat sleeping law /dead law (hukum yang tidur atau hukum yang mati), pengujian undang-undang dengan melihat respon sosial menjadi penting, karena melepaskan undang-undang dengan respon sosial berarti menghilangkan makna undangundang itu sendiri.

Review legislasi nasional ini harus dilakukan dengan melihat kepentingan nasional secara ideologis (Pancasila dan UUD RI 1945) dan sosial, dan akan mengevaluasi perundangundangan dari jaman kolonial hingga jaman reformasi saat ini, karena secara ideologis dan sosiologis telah terjadi perubahan secara prinsipil dan perkembangan yang cepat dari masyarakat, perubahan ini menyebabkan banyak perundang-undangan yang tidak lagi mampu dikontekstualisasikan dalam kodisi saat ini.

Review ini juga akan mengurangi undangundang yang selama ini menjadi beban dalam mendorong pembangunan nasional, mendorong harmonisasi antar kebijakan dan pengaturan. Review Secara Menyeluruh ini juga harusnya menghasilkan rekomendasi susbtansi yang harus dicabut dan dilakukan perbaikan. Review ini akan membantu menghasilkan Program Legislasi Nasional (Prolegnas) yang lebih terarah dan fokus Prolegnas

\section{b. Perubahan mekanisme Pembahasan Undang-undang di DPR,}

Mekanisme yang lebih efektif dibutuhkan dalam pembentukan undang-undang di DPR, yang juga melibatkan Pemerintah dan DPD berdasarkan putusan putusan Nomor 92/ PUU-X/2012 Mahkamah Konstitusi (MK), saat 
ini mekanisme pembahasan undang-undang, berdasarkan Undang-Undang Nomor 27 Tahun 2009 tentang MPR, DPR, DPD, dan DPRD (MD3) dan Undang-Undang Nomor No. 12 Tahun 2011 tentang Pembentukan Peraturan Perundangundangan (P3) Masih menempatkan DPD hanya sebatas memberi masukan dan usulan, tidak masuk dalam pembahasan undangundang, sehingga faktanya pemerintah dalam membahas undang-undang harus berhadapan dengan fraksi-fraksi yang merupakan perangkat penunjang di DPR, dan inilah yang merumitkan pembahasan karena pemerintah harus mendapatkan persetujuan dari semua fraksi yang ada di DPR apabila membahas undangundang, satu fraksi saja yang menolak maka undang-undang tidak dapat disetujui. Hal ini bertentangan dengan amanah konstistusi dimana pemerintah berhadapan dengan DPR. Seharusnya DPR dalam pembahasan undangundang tidak diwakili oleh fraksi tetapi sudah satu suara sebagai lembaga DPR. Berdasarkan putusan MK tersebut pembahasan akan di arahkan pada pembahasan yang akan dilakukan oleh tiga lembaga yaitu presiden, DPD dan DPR. Ini akan mempermudah proses politik dalam pembahasan undang-undang karena hanya tiga lembaga, bukan lagi sembilan fraksi dengan tidak mengajak DPD seperti saat ini.

Perubahan mekanisme yang lebih efektif ini juga harus ditunjang dengan mendesain mekanisme pembahasan yang terukur dalam pembahasan dan kualitas pembahasan, yaitu dengan cara merubah tahapan atau mekanisme pembahasan dan memberlakukan sistem pembatasan waktu pembahasan perundang undangan.
Kemudian pembentukan perundangundangan harusnya didorong pada ranah pembahasan policy yang lebih substantif dalam perundang-undangan itu sendiri, tidak lagi diarahkan pada Daftar Infentaris Masalah (DIM) atau teknis drafter perundang-undangan, seharusnya perdebatan yang penting dilakukan dahulu adalah substansi pengaturan yang harus disepakati, perdebatan adalah pada ranah substansial, terkait proses perancangan kemudian akan menjadi tahapan kedua yang akan mengikuti hasil dari substansi tersebut. Sampai saat ini mekanisme DIM menjadi salah satu mekanisme yang sangat tidak efektif dalam mendorong pembahasan yang lebih baik.

Perubahan mekanisme merupakan konsekwensi dari perubahan orientasi Legislasi yang lebih berkualitas dan dengan cepat dapat merespon kebutuhan dari masyarakat, pendekatan DIM terbukti menjadikan pemaknisme Legislasi kita semakin lama, dengan merubah pendekatan maka pembahasn utama akan diarahkan pada konsep kebijakan yang substansial, terhada teknik perundangundangannya atau penyusunan redaksi cukup diberikan kepada Tim perancang yang nantinya harus mengikuti substansi yang telah di sepakati.

Kegiatan dan masa pembahasan bisa dilakukan dengan cara, Pembahasan Pertama Penjelasan Konsep Undang-undang yang akan diatur yang diusulkan oleh lembaga yang menginisiasi, dibatasi waktu maksimal 2 hari, kemudian Konsep akan diserahkan ke lembaga lain untuk dikaji dan diteliti dengan jangka waktu maksimal 15 Hari, setelah itu dilakukan pertemuan kedua respon dari lembaga setelah membaca konsep, diberikan waktu maksimal 2 
Hari, kemudian kembali diserahkan ke lembaga inisiator undang-undang selama maksimal 5 Hari, tahapan ketiga adalah pembahasan bersama dan pencapaian kesepakat ditingkat komisi selama maksimal 15 Hari, setelah itu hasilnya diserahkan ke Tim Perancang selama maksimal 5 hari, dan hasilnya akan dibahas dalam komisi maksimal 5 Hari, kemudian dalam 2 hari sudah dapat di plenokan, dari total gambaran tersebut waktu yang dibutuhkan untuk satu undang undang adalah 51 Hari.

Manajemen ini mendorong terjadinya percepatan dalam pembahasan undang undang, yang artinya mendorong pula mekanisme politik yang lebih cepat dalam memutuskan kepentingan masyarakat dan negara.

\section{c. Pembatasan Jangka waktu Undang- undang.}

Pembatasan jangka waktu undangundang merupakan mekanisme yang didasari oleh pemahaman cepatnya perkembangan masyarakat secara nasional dan global, diiringi pesatnya teknologi dan cara pandang dalam dimensi sosial, konsekuensi ini jelas bahwa undang-undang kadang terlambat merespon perubahan tersebut, belum lagi respon dari aspek penegakan hukumnya, sehingga metode pengaturan dan cara pandang akan kejahatan dapat berubah, bisa jadi dari 5 tahun sebelumnya sebuah peristiwa belum menjadi pidana, saat ini sudah berubah menjadi peristiwa pidana.

Pembatasan jangka waktu undang-undang ini juga dapat dimaknai sebagai mekanisme otomatis dalam melakukan evaluasi terhadap undang-undang, karena suatu perundang undangan akan otomatis tidak berlaku dalam kurun waktu tertentu, dan mendorong lembaga legislasi melakukan evaluasi dalam perundangundang tersebut. Sehingga mekanisme evaluasi perundang undang otomatis harus melembaga di DPR, karena begitu suatu perundang-undang akan memasuki masa "Kadaluarsanya" maka akan ada mekanisme yang akan membahas apakah perundang-undangan tersebut akan diubah atau disahkan lagi menjadi undang undang.

Secara umum politik hukum legislasi telah didorong dengan Undang-Undang Nomor 10 Tahun 2004 sebagaimana telah dicabut dengan Undang-Undang Nomor 12 Tahun 2011 tentang Pembentukan Peraturan Perundang-undangan, secara umum tentunya telah mendorong sebuah mekanisme legislasi yang lebih rasional, tetapi masih terdapat kelemahan dalam membangun sistem legislasi yang sistematis dan berkesinambungan seperti cycle proses. Mekanisme saat ini seperti mesin yang hanya mengeluarkan produk tetapi tidak mendorong pengawasan dari kualitas produk tersebut, karena kualitas produksi hanya dapat diketahui berhasil dari respon pengguna produk tersebut, dalam hal ini masyarakat. Perbandingan mekanisme pembentukan dapat dilihat dalam gambar berikut ini: 
Gambar 1: Tahapan Pembentukan Peraturan Perundang-undangan

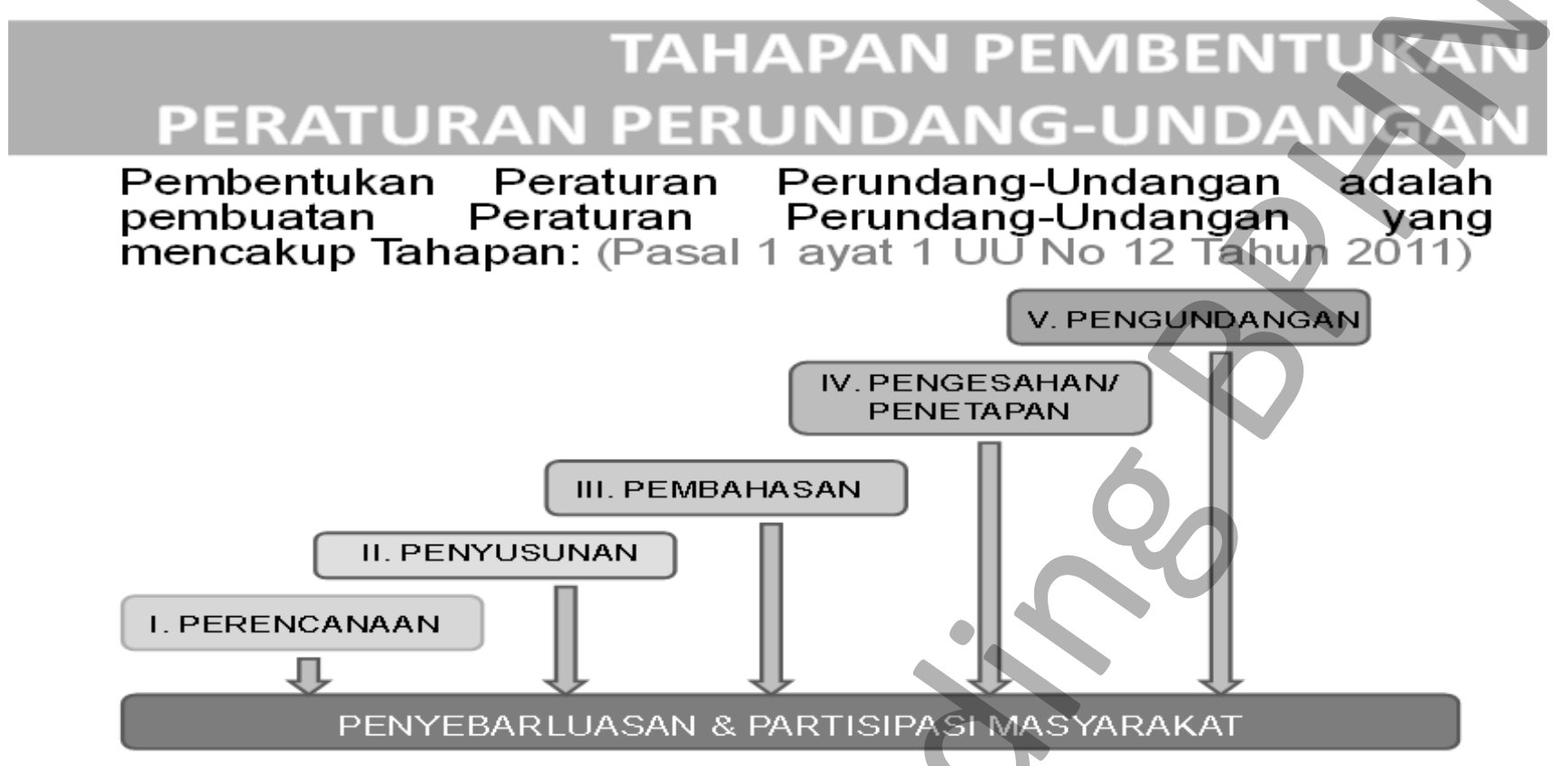

\section{Alur Pembentukan Undang-undang menurut UU 12 tahun 2011}

Sumber: Makalah Kepala Badan Pembinan Hukum Nasional, Presentasi di Bappenas, 2013.

Gambar 2: Intergrasi Perumusan Kebijakan dan Regulasi

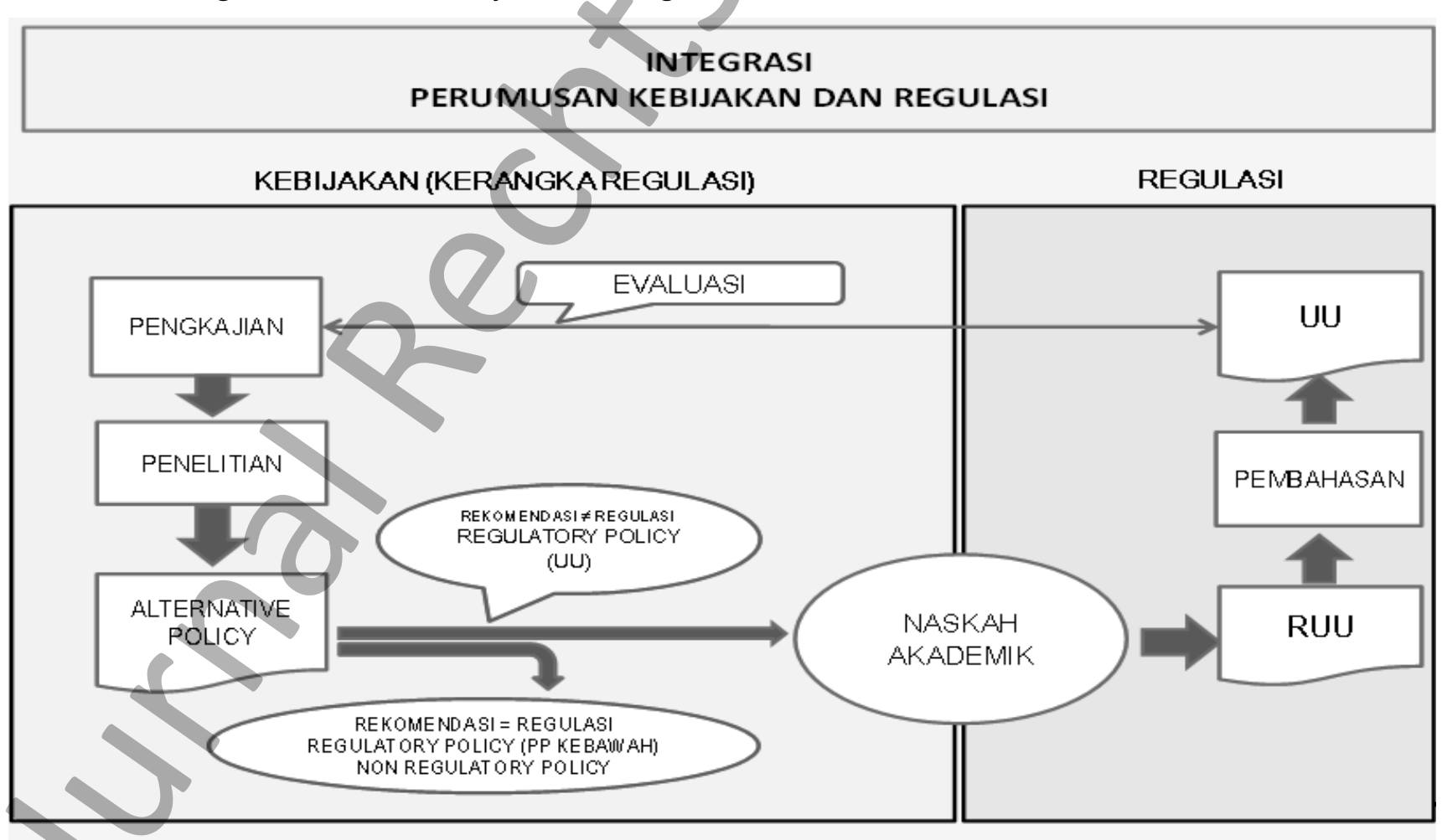

Sumber: Makalah Badan Perencanaan Pembangunan Nasional/Direktorat Analisa Peraturan Perundang-undangan, Presentasi di Bappenas (2013) 
Dari perbandingan kedua alur tersebut maka perbaikan proses perundang-undangan masih membutuhkan penekanan dalam hal Evaluasi peraturan perundang-undangan, mekanisme inilah yang belum masuk dalam proses pembentukan perundang-undangan diindonesia, evaluasi akan membantu melihat kualitas dari produk legislasi yang dihasilkan apakah efektif atau tidak, apakah sudah mendorong pencapaian tujuan undang-undang atau tidak.

\section{E. Penutup}

Hukum merupakan sebuah produk sosial yang dilakukan untuk membantu penataan dalam sistem sosial, untuk itu mendekatkan legislasi dengan proses sosial yang ada dapat menghasilkan perundang-undangan yang lebih baik. Tuntutan besar ini sampai saat ini ternyata masih belum maksimal di hasilkan, terbukti produk undang-undang masih menjadi bagian dari masalah dinegeri ini.

Kesimpulan dari pembahasan ini adalah, untuk menghasilkan kualitas yang berbeda dengan kualitas legislasi saat ini membutuhkan perubahan proses dalam menghasikan produk tersebut dalam hal ini produk legislasi atau undang-undang, tanpa perubahan dalam mekanisme tersebut maka tidak bisa lagi kita berharap terjadi perubahan kualitas dengan mesin proses yang sama. Proses tersebut sengat penting selain kualitas sumberdaya manusia yang terlibat dalam proses tersebut.

Walaupun perundang-undangan mempunyai kelemahan dalam konteks dan kaku dalam teksnya tetapi sebagi salah satu metode pengaturan maka undang-undang tentunya tetap menjadi alat utama dalam melakukan pencapaian negara, sehingga buruknya perbaikan dalam perundang-undangan mengakibatkan tidak maksimalnya mekanisme kenegaraan dalam mencapai pembangunan. Sudah saatnya cara-cara yang lebih progresif dilakukan, karena perubahan itu pasti, tetapi kualitas perubahan yang baik atau buruk itu adalah pilihan.

Rekomendasi yang perlu dilaksanakan adalah, Pembatasan Jangka waktu Undangundang Pertama, Review Legislasi Nasional. Program review perundang-undang menjadi kebutuhan sebagai alat evaluasi perundangundangan saat ini, untuk mengetahui mana undang-undang yang penting untuk dirubah dan penting untuk dipertahankan. Kedua, Perubahan mekanisme Pembahasan Undang-undang di DPR, merubah mekanisme pembahasan undang-undang di DPR hanya dilakukan oleh pemerintah, DPD, dan DPR untuk mengefektifkan pembahasan UU. kemudian Mengganti mekanisme DIM dalam manajemen pembahasan di DPR menjadi mekanisme pembahasan kebijakan secara umum, tidak lagi hanya membahas kata dan kalimat dalam pasalpasal. Kemudian melakukan pembatasan waktu pembahasan oleh pemerintah, DPD dan DPR sehingga mendorong melakukan konsensus politik dengan cepat dan menghasilkan UU dengan cepat. Ketiga, pembatasan masa berlaku tiap undang-undang, yang bertujuan untuk mendorong melakukan up date perundangundangan dengan perkembangan masyarakat dan evaluasi produk undang-undangan.

Pentingnya perubahan mekanisme pembahasan dan perundang-undangan tentunya menuntut langkah tegas dari Presiden dan Elit politik dalam mendorong perubahan yang lebih baik dalam politik hukum perundang-undangan saat ini. Tidak bisa lagi negara ini diam ditempat dalam permasalahan saat ini. Perubahan progresif adalah solusi perubahan bangsa. 


\section{DAFTAR PUSTAKA}

\section{Buku}

Badan Pembinaan Hukum Nasional, Perencanaan Pembangunan Hukum Nasional 2015-2019, Pusat Perencanaan Pembangunan Hukum Nasional (Jakarta: Badan Pembinaan Hukum Nasional, Tahun 2012).

Budiman, Arief, Teori Negara; Negara, Kekuasaan dan Ideologi (Jakarta: Gramedia Pustaka Utama, 1997).

Campbell, Tom and Adrienne Stone (Ed.), Law and Democracy (Burlington: Dartmouth Publishing Company-Ashgate Publishing Limited, 2003).

Farida Indrati Soeprapto, Maria, IImu Perundangundangan Dasar-dasar dan Pembentukannya (Yogyakarta: Kanisius, 1998).

Hamidi, Jazim dan Budiman N.P.D. Sinaga, Pembentukan Peraturan Perundang-undangan dalam Sorotan: Undang-Undang Nomor 10 Tahun 2004 Tentang Pembentukan Peraturan Perundang-undangan Dilengkapi dengan Analisa Kritis (Jakarta: Tatanusa, 2005).

Hartono, C.F.G. Sunaryati, Penelitian Hukum Di Indonesia Pada Akhir Abad Ke-20, (Bandung: Alumni, 1994)

Jimly Asshiddiqie, Perihal Undang-Undang. (Jakarta: Konstitusi Press, 2006.)

Mahfud MD, Moh., Pergulatan Politik dan Hukum di Indonesia (Yogyakarta: Gama Media, 1999).

Mahfud MD, Moh., Politik Hukum di Indonesia (Jakarta: Pustaka LP3ES, 1998).

Nonet, Philippe dan Philip Selznick, Law \& Society in Transition: Toward Responsive Law. (London: Harper \& Row, Publishers, 1978).

Pusat Studi Kebijakan Hubungan Pusat dan Daerah, Pembangunan Hukum Dan Konflik UndangUndang Bidang Sektoral (Jakarta: PSHK, 2009).

Rahardjo, Satjipto, Menggagas Hukum Progresif Indonesia (Semarang: Kerjasama Pustaka Pelajar, IAIN Walisongo dan Program Doktor IImu Hukum UNDIP, 2006).

Sinaga, Budiman N.P.D., IImu Pengetahuan Perundang-udangan (Yogyakarta: UUI Press, 2005)

Soekanto, Soerjono dan Sri Mamudji, Penelitian Hukum Normatif (Suatu Tinjauan Singkat) (Jakarta: Rajawali Pers, 2001).

Soemitro, Ronny Hanitijo, Metodologi Penelitian Hukum dan Jurimetri, (Jakarta: Cetakan Kelima, Ghalia Indonesia, 1994).
Soetandyo Wignjosoebroto, Hukum, Paradigma Metode dan Dinamika Masalahnya, (Jakarta, Elsam dan Huma, 2002).

Syaukani, Imam dan A. Ahsin Thohari, Dasar-Dasar Politik Hukum (Jakarta: Raja Grafindo Persada, 2006).

Wignjosoebroto, Soetandyo, Prof Tjip dan Ajaran Hukum Progresifnya: Sebuah Pengantar Ringkas, (Jakarta: Huma, 2011).

\section{Makalah / Artikel / Prosiding / Hasil Penelitian}

Asshiddiqie, Jimly, "Struktur Ketatanegaraan Indonesia Setelah Perubahan Keempat UUD RI Tahun 1945" (Makalah disampaikan Seminar Pembangunan Hukum Nasional Viii Tema Penegakan Hukum Dalam Era Pembangunan Berkelanjutan Diselenggarakan Oleh Badan Pembinaan Hukum Nasional Departemen Kehakiman Dan Hak Asasi Manusia RI, Denpasar, 14-18 Juli 2003).

Badan Perencanaan Pembangunan Nasional (Bappenas), "Pedoman Penerapan Reformasi Regulasi" (Reformasi Regulasi, Bappenas, Jakarta 24 Nopember 2011).

Direktorat Analisa Peraturan Perundang-Undangan BAPPENAS, "Paper Penelitian Pemetaan Hasil Identifikasi Terhadap Undang-Undang Sektor Yang Berpotensi Bermasalah" (Makalah disampaikan pada Workshop Koordinasi Strategis Analisa Peraturan PerundangUndangan, Direktorat Analisa Peraturan Perundang-Undangan, BAPPENAS, Jakarta 5 Desember 2012).

Setiadi, Wicipto, "Mewujudkan Perencanaan Pembentukan Undang-Undang yang Terencana, Terpadu dan Sistematis Kaitannya dengan Konsep Reformasi Regulasi" (Makalah disampaikan dalam Konsultasi Publik Reformasi Regulasi, BAPPENAS, 21 Mei 2013).

Soetandyo Wignjosoebroto, "Negara Hukum Dan Permasalahan Akses Keadilan Di NegeriNegeri Berkembang Pasca-Kolonial" (Makalah disamapaikan dalam Konferensi Dan Dialog Hukum Nasional, Jakarta, Hotel Bidakara 9-10 Oktober 2012).

Suharto, Edi, "Peta Dan Dinamika Welfare State Di Beberapa Negara: Pelajaran apa yang bisa dipetik untuk membangun Indonesia?" (Makalah disampaikan pada Seminar "Mengkaji Ulang Relevansi Welfare State dan Terobosan melalui Desentralisasi-Otonomi di Indonesia", 
Institute for Research and Empowerment (IRE) Yogyakarta dan Perkumpulan Prakarsa Jakarta, bertempat di Wisma MM Universitas Gadjah Mada, Yogyakarta 25 Juli 2006).

Susanti, Bivitri, "Problem Kelembagaan Dalam Proses Legislasi" (Makalah disampaikan dalam "Seminar Memperbaiki Kualitas Pembuatan
Undang-Undang di Indonesia," The Habibie Centre, di Hotel Nikko, Jakarta, 8 Maret 2007).

Widiarto, Aan Eko, "Mengukur Kualitas Legislasi Dalam Perspektif Legisprudence", (Makalah disampaikan dalam Konfrensi Negara Hukum, Hote Bidakara Tahun 2012). 